\title{
Herbage Production and Quality of Grasses with Livestock and Wildlife Value in Texas
}

\author{
W.D. PITMAN AND E.C. HOLT
}

\section{Abstract}

Large economic returns to management of grazing lands for wild life are often realized throughout Texas. Management of perennial pastures for livestock grazing and seed for game bird feed is restricted by the limited number of forage species with desirable seed production characteristics. Selected grasses with the desired seed production potential were evaluated for herbage yield and quality under intensive management. Green sprangletop (Leptochloa dubia (H.B.K.) Nees), plains bristlegrass (Setaria macrostachya H.B.K.), and 2 selections of kleingrass (Panicum coloratum L.), Kleingrass 75 and Kleingrass $75-25$, were harvested at 2, 4, and 8-wk frequencies at a 5-cm stubble height throughout the 1978 and 1979 growing seaons. In vitro digestible organic matter (IVDOM) and percent leaf were determined at each harvest date. Herbage yields were progressively greater with less frequent harvests. However, optimum yields of highly digestible, leafy herbage were obtained at the 4-wk harvest frequency. Kleingrass 75 herbage yield (2-yr average of $10,042 \mathrm{~kg} / \mathrm{ha}$ at the 4 -wk frequency) was highest followed closely by Kleingrass 75-25. Green sprangletop yield was limited by lack of persistence. Herbage yield of plains bristlegrass was low, but its tolerance of frequent defoliation and limited moisture indicate potential value in harsh environments. IVDOM of green sprangletop (2-yr average of $63.8 \%$ at the 4-wk harvest frequency) surpassed Kleingrass 75-25 (62.1\%) and Kleingrass $75(60.7 \%)$. Both kleingrass selections produced high yields of quality herbage.

Extensive areas in Texas have been planted to introduced grasses which either produce very little to no seed or produce seed which is not acceptable as feed for birds. Management of grazing land for wildlife and game birds in addition to livestock is currently of tremendous economic importance. Of the extensively planted introduced grasses in Texas, only kleingrass (Panicum coloratum L.) appears to have potential to provide both forage for livestock and seed acceptable to game birds. From the numerous native grasses, green sprangletop (Leptochloa dubia (H.B.K.) Nees) and plains bristlegrass (Setaria macrostachya H.B.K.) were selected as species with potential to provide desirable seed for game bird feed.

In a feeding study with caged bobwhite quail (Colinus virginianus), Hendler (1979) found that quail would consume kleingrass, green sprangletop, and plains bristlegrass seed with kleing ra ss seed eaten more readily than seed of the other 2 grasses. In field plantings Hendler obtained higher seed yields in these 3 grasses with periods of deferred forage utilization than with frequent harvesting.

Kleingrass has been widely planted in pure stands throughout South and Central Texas and as a component of mixed range seedings in West Texas. Forage yields of kleingrass vary with management and climatic conditions across the area of its produc-

Authors are assistant professor, University of Florida, Agricultural Research Center, Ona 33865 (formerly graduate student, Texas A\&M University); and professor, Department of Soil and Crop Sciences, Texas A\&M University, College Station 77843 .

This research was supported, in part, by the R.M. Kleberg Research Foundation and submitted as Texas Agricultural Experiment Station Technical Article 17026

Manuscript received August 20, 1981 . tion. Five-year average yields of kleingrass forage under different management practices ranged from $3500 \mathrm{~kg} / \mathrm{ha}$ to $6700 \mathrm{~kg} / \mathrm{ha}$ at College Station, Texas (Holt and Evers 1976). At Weslaco, Texas, 3-year average annual forage production of kleingrass ranged from $9700 \mathrm{~kg} / \mathrm{ha}$ under dryland conditions to $18000 \mathrm{~kg} / \mathrm{ha}$ under irrigation (Woodward 1980). At Beeville, Texas, three-year average kleingrass production varied from $3000 \mathrm{~kg} / \mathrm{ha}$ with no applied fertilizer to $6300 \mathrm{~kg} /$ ha with $67 \mathrm{~kg} / \mathrm{ha}$ nitrogen fertilization (Conrad 1976). Under grazing in the Texas Coastal Bend, McCawley and Dahl (1980) reported kleingrass yields of $11,570 \mathrm{~kg} / \mathrm{ha}$ with beef production of $280 \mathrm{~kg} / \mathrm{ha}$. Kleingrass seed production is difficult to determine due to seed shattering and indeterminate flowering. Seed harvests have yielded from 125 to $225 \mathrm{~kg}$ / ha at College Station, Texas (Holt and Evers 1976).

Green sprangletop produces excellent quality forage. However, it is not persistent under grazing, often performing as a short-lived perennial under moderate to heavy grazing. Green sprangletop has been used in mixed range seedings to provide forage in the initial years after reseeding while other grasses in the mixture are becoming established. Gould (1975) pointed out that this grass is widespread and highly palatable but is seldom abundant. Plains bristlegrass is an important native forage species throughout much of its area of distribution. It is more persistent under grazing than green sprangletop. Since both of these grasses are commonly found as components of mixed plant communities, limited information is available on their potential forage production in pure stands.

This study was conducted to determine the herbage production and digestibility of green sprangletop, plains bristlegrass, and 2 selections of kleingrass at different harvest frequencies. The resulting herbage yield and quality data are needed in combination with seed production data for development of utilization systems for the dual use of grassland for livestock production and game bird habitat.

\section{Materials and Methods}

Green sprangletop, plains bristlegrass (Soil Conservation Service, PMT 4022), and 2 selections of kleingrass (Kleingrass 75 and Kleingrass $75-25$, the latter being a selection for improved forage quality) were established as pure stands in field plots in the early spring of 1978. Seedlings were transplanted to the field in a randomized block design with 4 replications. Treatments consisted of 3 harvest frequencies and 4 grasses in a factorial arrangement. Each of the 48 experimental units ( 4 replications $\times 4$ grasses $\times 3$ harvest frequencies) consisted of a plot of 4 rows $4.5 \mathrm{~m}$ long on $50-\mathrm{cm}$ row spacings. Each row contained 15 equally spaced plants. The plantings were in a Norwood clay loam soil (fine, loamy, mixed, thermic, Typic Udifluvents) in the Brazos River Bottom of Burleson County, Texas.

Herbage was harvested from the 2 center rows in each plot over a 24-wk period during the 1978 and 1979 growing seasons. All plant growth was cut back to the 5-cm harvest stubble height on May 15, 1978, and on April 16, 1979. Herbage was harvested on the prescribed schedule through October 30, 1978, and October 1, 1979. 
Table 1. Mean herbage yields (kg/ha) during the 1978 and 1979 growing seasons.

\begin{tabular}{|c|c|c|c|c|c|c|c|c|}
\hline & \multicolumn{2}{|c|}{ Kleingrass 75} & \multicolumn{2}{|c|}{ Kleingrass $75-25$} & \multicolumn{2}{|c|}{ Green sprangletop } & \multicolumn{2}{|c|}{ Plains bristlegrass } \\
\hline & 1978 & 1979 & 1978 & 1979 & 1978 & 1979 & 1978 & 1979 \\
\hline $\begin{array}{l}\text { Herbage yield } \\
2 \text { wk harvest } \\
4 \text { wk harvest } \\
8 \text { wk harvest }\end{array}$ & $\begin{array}{l}4807 a^{1} C^{2} \\
11464 a B \\
17857 a A\end{array}$ & $\begin{array}{r}3333 \mathrm{aC} \\
8620 \mathrm{aB} \\
12484 \mathrm{aA}\end{array}$ & $\begin{array}{r}3997 \mathrm{aC} \\
10636 \mathrm{aB} \\
16336 \mathrm{aA}\end{array}$ & $\begin{array}{r}2110 \mathrm{bC} \\
8120 \mathrm{aB} \\
11158 \mathrm{aA}\end{array}$ & $\begin{array}{r}3946 \mathrm{aC} \\
8614 \mathrm{bB} \\
15002 \mathrm{aA}\end{array}$ & $\begin{array}{l}1629 \mathrm{bB} \\
5597 \mathrm{bA} \\
6752 \mathrm{bA}\end{array}$ & $\begin{array}{l}2561 \mathrm{bB} \\
6753 \mathrm{bA} \\
7910 \mathrm{bA}\end{array}$ & $\begin{array}{l}2478 \mathrm{abB} \\
7092 \mathrm{abA} \\
7554 \mathrm{bA}\end{array}$ \\
\hline $\begin{array}{l}\text { Leaf yield } \\
2 \text { wk harvest } \\
4 \text { wk harvest } \\
8 \text { wk harvest }\end{array}$ & $\begin{array}{l}2912 \mathrm{aC} \\
5141 \mathrm{aA} \\
4118 \mathrm{aA}\end{array}$ & $\begin{array}{l}2085 \text { a B } \\
4244 \text { a A } \\
3968 \text { a A }\end{array}$ & $\begin{array}{l}2394 \mathrm{aB} \\
4623 \mathrm{abA} \\
4233 \mathrm{aA}\end{array}$ & $\begin{array}{l}1305 \mathrm{bB} \\
3993 \mathrm{aA} \\
3353 \mathrm{aA}\end{array}$ & $\begin{array}{l}2658 \mathrm{aA} \\
4103 \mathrm{bA} \\
4206 \mathrm{aA}\end{array}$ & $\begin{array}{l}991 \mathrm{bB} \\
2891 \mathrm{bA} \\
2212 \mathrm{bA}\end{array}$ & $\begin{array}{l}1189 \mathrm{bB} \\
1755 \mathrm{cA} \\
1362 \mathrm{bAB}\end{array}$ & $\begin{array}{c}1400 \mathrm{bB} \\
2904 \mathrm{bA} \\
1998 \mathrm{bB}\end{array}$ \\
\hline $\begin{array}{l}\text { Stem yield } \\
2 \text { wk harvest } \\
4 \text { wk harvest } \\
8 \text { wk harvest }\end{array}$ & $\begin{array}{r}1895 \mathrm{aC} \\
6323 \mathrm{aB} \\
13739 \mathrm{aA}\end{array}$ & $\begin{array}{l}1248 \mathrm{aC} \\
4376 \mathrm{aB} \\
8516 \mathrm{aA}\end{array}$ & $\begin{array}{r}1603 \mathrm{abC} \\
6013 \mathrm{abB} \\
12103 \mathrm{abA}\end{array}$ & $\begin{array}{l}805 \mathrm{abC} \\
4127 \mathrm{aB} \\
7805 \mathrm{aA}\end{array}$ & $\begin{array}{r}1288 \mathrm{bC} \\
4511 \mathrm{cB} \\
10796 \mathrm{bA}\end{array}$ & $\begin{array}{r}638 \mathrm{bC} \\
2706 \mathrm{bB} \\
4540 \mathrm{bA}\end{array}$ & $\begin{array}{l}1372 \mathrm{abC} \\
4998 \mathrm{bcB} \\
6548 \mathrm{cA}\end{array}$ & $\begin{array}{l}1078 \mathrm{bC} \\
4188 \mathrm{aB} \\
5556 \mathrm{bA}\end{array}$ \\
\hline
\end{tabular}

IMeans within each year in each line followed by the same lower case letter are not significantly different at the .05 level.

${ }^{2}$ Means for each parameter in a column followed by the same upper case letter are not significantly different at the .05 level.

Harvest frequencies were 2,4 , and 8 wk with total yields each year consisting of 12 harvests at the 2-wk frequency, 6 harvests at the 4-wk frequency, and 3 harvests at the 8-wk frequency. A complete fertilizer was applied to all plots at the rate of $200 \mathrm{~kg} / \mathrm{ha}$ of $\mathrm{N}, \mathrm{P}_{2} \mathrm{O}_{5}$ and $\mathrm{K}_{2} \mathrm{O}$ per year in 3 equal applications each year at the beginning of each 8-wk harvest period.

Separate samples were taken for forage quality and yield determinations. Samples for forage quality analysis were taken from the same 4 plants in each plot at each harvest date. This plant material was immediately separated into leaf blades and stems (including leaf sheaths and inflorescences when present). After drying, the separate fractions were weighed for determination of percent leaf. In vitro digestible organic matter (IVDOM) was determined on both leaf and stem fractions by the Tilley and Terry (1963) technique as modified by Goering and Van Soest (1970). Herbage yield, percent leaf, whole plant IVDOM, leaf IVDOM, and stem IVDOM were subjected to analysis of variance with significantly different means separated by Duncan's multiple range test.

\section{Results and Discussion}

\section{Herbage Yield}

Herbage production increased as harvest frequency decreased for both kleingrass selections in 1978 and 1979 (Table 1). Similar increases in green sprangletop herbage production were obtained with less frequent harvest in 1978 (Table 1). Increases in herbage yield of green sprangletop in 1979 and plains bristlegrass in both years from the 4-wk to 8-wk harvest frequencies were comparatively small. Although total herbage yield was consistently greater at the 8-wk harvest frequency, leaf yield was as great or greater at the 4-wk harvest frequency (Table 1) for all grasses. The increased yields obtained from 2-wk to 4-wk harvest frequencies were due to increase in both leaf and stem production. Increased yields from 4-wk to 8-wk harvest frequencies can be attributed to increased stem production (Table 1) with leaf senescence reducing leaf yields at the 8-wk harvest frequency in some cases.

Kleingrass 75 was consistently the leading herbage producer. However, Kleingrass 75-25 yielded significantly less than Kleingrass 75 only at the 2 -wk harvest frequency in 1979 . From the total yields (Table 1), yields at the individual harvest dates (data not shown), and visual observation of plants in the field, it appears that the production potential of Kleingrass $75-25$ is not different from that of Kleingrass 75 , but plant vigor under adverse conditions of severe defoliation and low moisture may be less for Kleingrass 75-25 than for Kleingrass 75 .

Green sprangletop produced significantly less herbage than Kleingrass 75 in all cases except the 2-wk and 8-wk harvests in 1978 (Table 1). Vigor of green sprangletop was greatly reduced during the extremely dry summer of 1978 and continued to decrease during the 1979 growing season. In contrast to the other grasses in this study, stands of green sprangletop were greatly reduced by the end of the 1979 growing season, especially at the 2-wk harvest frequency.

Plains bristlegrass produced the lowest herbage yields at all ages in 1978 (Table 1). However, herbage production of plains bristlegrass was essentially the same in 1979 as in 1978; while production of the other grasses decreased greatly (Table 1). In 1979, herbage yield of plains bristlegrass was significantly less than that of the kleingrass selections only at the 8-wk harvest frequency (Table 1). This apparent tolerance of plains bristlegrass to frequent defoliation and moisture limitations is in agreement with its classification as an "increaser" plant on many rangeland sites in the eastern portion of its region of natural occurrence.

\section{Herbage Quality}

Whole plant IVDOM was generally highest for herbage at the 2-wk harvest frequency and lowest at the 8-wk frequency (Table 2). There were no significant differences in IVDOM of whole plants between 2-wk and 4-wk harvests during 1978. The differences in whole plant IVDOM between 2-wk and 4-wk harvest frequencies were less than the differences obtained between 4-wk and 8-wk harvest frequencies for all grasses. IVDOM of the separate leaf and stem fractions generally followed similar trends to those of whole plants with changes in harvest frequency. Decreased IVDOM from 4-wk old to 8-wk old stems was especially distinct (Table 2). Large decreases in percent leaf were obtained with increases in age of forage for all 4 grasses in both years (Table 2).

Green sprangletop generally had the highest IVDOM for whole plant, leaf, and stem materials (Table 2). Other differences in IVDOM among the four grasses were not consistent, but overall Kleingrass 75-25, Kleingrass 75 , and plains bristlegrass followed green sprangletop in order of decreasing IVDOM. Plains bristlegrass was lower in percent leaf than the other 3 grasses. Green sprangletop consistently had the highest numerical leaf percentage value, but the differences among grasses generally were not statistically significant.

\section{Summary and Conclusions}

The primary objective of grazing management for domestic livestock is the sustained production of adequate quantities of high quality forage. The pressure exerted on these 4 grasses with the 2-wk harvest frequency to a 5 -cm stubble height was too severe to reach acceptable forage production levels. Extending the growth period between harvests from 2 wk to 4 wk resulted in substantial increases in herbage production. Forage IVDOM was decreased but not excessively. A further extension of the growth period between harvests to $8 \mathrm{wk}$ resulted in still greater herbage yields. 
Table 2. Means' (\%) of forage quality values for herbage harvested during the 1978 and 1979 growing seasons (at three harvest frequencies).

\begin{tabular}{|c|c|c|c|c|c|c|c|c|}
\hline & \multicolumn{2}{|c|}{ Kleingrass 75} & \multicolumn{2}{|c|}{ Kleingrass $75-25$} & \multicolumn{2}{|c|}{ Green sprangletop } & \multicolumn{2}{|c|}{ Plains bristlegrass } \\
\hline & 1978 & 1979 & 1978 & 1979 & 1978 & 1979 & 1978 & 1979 \\
\hline $\begin{array}{l}\text { Whole plant IVDOM } \\
2 \text { wk harvest } \\
4 \text { wk harvest } \\
8 \text { wk harvest }\end{array}$ & $\begin{array}{l}64.2 \mathrm{~b}^{3} \mathrm{~A}^{4} \\
62.7 \mathrm{bA} \\
45.6 \mathrm{cB}\end{array}$ & $\begin{array}{l}63.8 \mathrm{bA} \\
58.6 \mathrm{bcB} \\
50.1 \mathrm{bC}\end{array}$ & $\begin{array}{l}64.9 \mathrm{abA} \\
64.5 \mathrm{abA} \\
49.0 \mathrm{bB}\end{array}$ & $\begin{array}{l}62.8 \mathrm{bA} \\
59.6 \mathrm{bB} \\
52.5 \mathrm{bC}\end{array}$ & $\begin{array}{r}66.8 \mathrm{aA} \\
66.1 \mathrm{aA} \\
52.4 \mathrm{aB}\end{array}$ & $\begin{array}{r}66.7 \mathrm{aA} \\
61.4 \mathrm{aB} \\
55.7 \mathrm{aC}\end{array}$ & $\begin{array}{l}59.0 \mathrm{cA} \\
59.4 \mathrm{cA} \\
45.1 \mathrm{cB}\end{array}$ & $\begin{array}{c}63.9 \mathrm{bA} \\
57.3 \mathrm{cB} \\
50.8 \mathrm{bC}\end{array}$ \\
\hline $\begin{array}{l}\text { Leaf IVDOM } \\
2 \text { wk harvest } \\
4 \text { wk harvest } \\
8 \text { wk harvest }\end{array}$ & $\begin{array}{l}65.4 \mathrm{bA} \\
67.2 \mathrm{aA} \\
60.2 \mathrm{aB}\end{array}$ & $\begin{array}{l}64.7 \mathrm{bcA} \\
61.9 \mathrm{aB} \\
58.3 \mathrm{aC}\end{array}$ & $\begin{array}{l}66.6 \mathrm{abB} \\
69.8 \mathrm{aA} \\
63.8 \mathrm{aC}\end{array}$ & $\begin{array}{l}63.5 \mathrm{cA} \\
63.4 \mathrm{aA} \\
61.0 \mathrm{aA}\end{array}$ & $\begin{array}{l}68.0 \mathrm{aA} \\
68.3 \mathrm{aA} \\
61.5 \mathrm{aB}\end{array}$ & $\begin{array}{l}67.0 \mathrm{aA} \\
63.2 \mathrm{aB} \\
62.3 \mathrm{aB}\end{array}$ & $\begin{array}{l}60.6 \mathrm{cA} \\
61.2 \mathrm{bA} \\
53.0 \mathrm{bB}\end{array}$ & $\begin{array}{l}65.5 \mathrm{abB} \\
61.6 \mathrm{aB} \\
58.8 \mathrm{aB}\end{array}$ \\
\hline $\begin{array}{l}\text { Stem IVDOM } \\
2 \text { wk harvest } \\
4 \text { wk harvest } \\
8 \text { wk harvest }\end{array}$ & $\begin{array}{l}62.5 \mathrm{aA} \\
59.1 \mathrm{bA} \\
41.3 \mathrm{bB}\end{array}$ & $\begin{array}{l}62.4 \mathrm{bA} \\
55.4 \mathrm{bB} \\
46.1 \mathrm{bC}\end{array}$ & $\begin{array}{l}62.3 \mathrm{aA} \\
60.5 \mathrm{bA} \\
43.8 \mathrm{bB}\end{array}$ & $\begin{array}{l}61.9 \mathrm{bA} \\
56.0 \mathrm{bB} \\
48.7 \mathrm{bC}\end{array}$ & $\begin{array}{l}64.1 \mathrm{aA} \\
64.3 \mathrm{aA} \\
49.0 \mathrm{aB}\end{array}$ & $\begin{array}{l}66.0 \mathrm{aA} \\
59.4 \mathrm{aB} \\
52.5 \mathrm{aC}\end{array}$ & $\begin{array}{l}57.5 \mathrm{bA} \\
58.8 \mathrm{bA} \\
43.4 \mathrm{bB}\end{array}$ & $\begin{array}{l}62.0 \mathrm{bA} \\
54.4 \mathrm{bB} \\
47.9 \mathrm{bC}\end{array}$ \\
\hline $\begin{array}{l}\text { Percent leaf } \\
2 \text { wk harvest } \\
4 \text { wk harvest } \\
8 \text { wk harvest }\end{array}$ & $\begin{array}{l}60.2 \mathrm{bA} \\
44.9 \mathrm{aB} \\
23.0 \mathrm{bC}\end{array}$ & $\begin{array}{l}62.7 \mathrm{aA} \\
49.2 \mathrm{aB} \\
31.9 \mathrm{aC}\end{array}$ & $\begin{array}{l}59.2 \mathrm{bA} \\
43.2 \mathrm{aB} \\
25.9 \mathrm{abC}\end{array}$ & $\begin{array}{l}61.7 \mathrm{aA} \\
48.9 \mathrm{aB} \\
30.1 \mathrm{abC}\end{array}$ & $\begin{array}{l}67.3 \mathrm{aA} \\
47.9 \mathrm{aB} \\
28.0 \mathrm{aC}\end{array}$ & $\begin{array}{l}62.7 \mathrm{aA} \\
51.7 \mathrm{aB} \\
33.0 \mathrm{aC}\end{array}$ & $\begin{array}{l}46.1 \mathrm{cA} \\
26.0 \mathrm{bB} \\
17.1 \mathrm{cC}\end{array}$ & $\begin{array}{l}56.0 \mathrm{aA} \\
40.6 \mathrm{bB} \\
26.3 \mathrm{bC}\end{array}$ \\
\hline
\end{tabular}

'These are weighted means calculated by multiplying percent IVDOM and percent leaf, respectively, of each harvest by the yield for that harvest, totaling the products, and dividing this total by the total yield for the year.

2Whole plant IVDOM was calculated from percent leaf and IVDOM of the separate leaf and stem fractions.

"Means within each year in each line followed by the same lower case letter are not significantly different at the .05 level.

${ }_{4}^{4}$ Means for each parameter in a column followed by the same upper case letter are not significantly different at the .05 level.

However, this increased yield was primarily stem material with low IVDOM levels. Reduced consumption of this low quality, stemmy grass would likely further limit animal performance. Optimum performance of grazing livestock on these grasses would be expected at grazing pressures similar to the 4-wk harvest frequency in this study.

In addition to immediate considerations for livestock production, the long-term maintenance of plant stands must be considered. The reduced yields of the two kleingrass selections from 1978 to 1979 may have been due to climatic conditions. However, reduced plant vigor due to excessive defoliation may have been involved especially at the most frequent defoliation level. Actual stand deterioration occurred in green sprangletop with greater stand loss under the most frequent defoliation. Management of green sprangletop for forage production could not be achieved over extended periods at defoliation levels similar to those used in this study. Either plant selection for longevity or a less intensive management system is necessary for sustained forage production from green spranglctop. Forage production of plains bristlegrass was low the first year. However, there was little decrease in plains bristlegrass yield in the second year even at the most frequent defoliation level. This suggests a tolerance of heavy utilization.

Both maintenance of plant vigor and increased seed production could be achieved with less frequent plant defoliation. At the 8-wk harvest frequency, normal plant ontogeny was permitted resulting in mature plants of all 4 grasses which were observed to have large amounts of seed. At the 4-wk and 2-wk harvest frequencies progressively less seed was produced since plants had less opportunity to develop beyond the vegetative stage. Management of warmseason perennial grasses for game bird feed may require less defoliation than is needed to maintain high quality forage. Some reduction in livestock production must be sacrificed for production of good seed crops. As mentioned in the introduction, Hendler (1979) reported excellent seed yields of these same species in systems involving periods of spring, summer, and fall deferment from grazing. Rotation systems would allow both intensive grazing management for production of high quality forage and areas of deferred grazing for seed production.

The kleingrass selections exhibited superior forage production potential among these grasses. Grazing studies are needed to determine whether the slight advantage in forage production shown by Kleingrass 75 will be offset by the higher digestibility obtained with Kleingrass 75-25 at the 4-wk and 8-wk harvest frequencies. The excellent digestibility of green sprangletop forage indicates that selection for forage production and plant persistence could have potential. Plains bristlegrass did not exhibit the desired yield potential under the conditions of this study. However, under extremely dry conditions, plains bristlegrass has potential to persist under more severe defoliation than the other grasses evaluated in this study.

\section{Literature Cited}

Conrad, B.E. 1976. Kleingrass 75. In: Holt, E.C. and R.D. Lewis (eds.) Grasses and legumes in Texas-development, production, and utilization. Texas Agr. Exp. Sta. Res. Monogr. 6.

Goering, H.K., and P.J. Van Soest. 1970. Forage fiber analysis. USDAARS Handb. 379. U.S. Government Printing Office, Washington, D.C.

Gould, F.W. 1975. The grasses of Texas. Texas A\&M Univ. Press, College Station.

Hendler, R.J. 1979. Grass management for forage and seed production. M.S. Thesis. Texas A\&M University.

Holt, E.C., and G.W. Evers. 1976. Establishment, management and seed production. In: Holt, E.C. and R.D. Lewis (eds.) Grasses and legumes in Texas-development, production, and utilization. Texas Agr. Exp. Sta. Res. Monogr. 6.

McCawley, P.F., and B.E. Dahl. 1980. Nutritional characteristics of high yielding exotic grasses for seeding cleared South Texas brushland. J. Range Manage. 33:442-445.

Tilley, J.M.A., and R.A. Terry. 1963. A two-stage technique for the in vitro digestion of forage crops. J. Br. Grassld. Soc. 18:104-111.

Woodward, W.T.W. 1980. Evaluation of selected forage species for South Texas. Texas Agr. Exp. Sta. MP-1459. 